\title{
PERKEMBANGAN FONOLOGI DALAM PEMBELAJARAN BAHASA INGGRIS PADA MAHASISWA PERHOTELAN DI SEKOLAH TINGGI PARIWISATA BALI INTERNASIONAL
}

\author{
Kadek Feni Aryati \\ kadekfeniaryati@yahoo.com \\ Universitas Udayana
}

\begin{abstract}
Abstrak
Penelitian ini bertujuan untuk membahas perkembangan fonologi dalam pembelajaran Bahasa inggris pada mahasiswa perhotelan. Meskipun mahasiswa sudah memiliki usia belasan atau puluhan tahun, bukan masa kanak-kanak lagi, namun sistem fonologisnya masih terus berkembang. Perkembangan fonologi ini disebut juga pemerolehan fonologi pada Bahasa, yang dalam ini adalah Bahasa inggris. Dengan metode kualitatif, langkah pertama yang dilakukan yaitu mengadakan penelitian dengan teknik rekam-catat, mentranskrip data, mengelompokkan data sesuai dengan tingkat perkembangan fonologis yang mencakup kefasihan mahasiswa dalam mengucapkan kosa-kata Bahasa inggris pada bidang perhotelan. Hasil penelitian ini diketahui bahwa mahasiswa Perkembangan fonologi terjadi melalui proses yang panjang dari dekode bahasa. Sebagian besar konstruksi morfologi mahasiswa akan tergantung pada kemampuannya menerima dan memproduksi unit fonologi. Dalam hal ini, mahasiswa tidak hanya menerima inventaris fonetik dan sistem fonologi tapi juga mengembangkan kemampuan menentukan bunyi mana yang dipakai untuk membedakan makna. Berkaitan dengan hal tersebut, pemerolehan fonologi pada penelitian ini berkaitan dengan proses konstruksi suku kata yang terdiri dari gabungan vokal dan konsonan. Bahkan dalam berbicara, anak menggunakan konsonan-vokal (KV) atau konsonan-vokal-konsonan (KVK). Proses lainnya berkaitan dengan asimilasi dan substitusi sampai pada persepsi dan produksi suara.

Kata kunci : Perkembangan fonologi, pembelajaran Bahasa inggris, mahasiswa perhotelan
\end{abstract}

\section{PENDAHULUAN}

Istilah perkembangan berkaitan dengan pemerolehan yang dipakai untuk padanan istilah Inggris acquisition, yakni proses penguasaan bahasa yang dilakukan oleh anak secara natural pada waktu dia belajar bahasa ibunya (native language). Istilah ini dibedakan dari pembelajaran yang merupakan padanan dari istilah Inggris learning. Dalam pengertian ini proses itu dilakukan dalam tatanan yang formal, yakni belajar di kelas dan di ajar oleh seorang dosen. Dengan demikan maka proses dari anak yang belajar menguasai bahasa ibunya adalah pemerolehan, sedangkan proses dari orang (umumnya dewasa) yang belajar di kelas adalah pembelajaran. Orang tua berkewajiban memelihara anak-anaknya dengan cara mendidik, menanamkan budi pekerti yang baik, mengajarinya akhlakakhlak yang mulia melalui keteladanan dari orang tuanya, dan juga berusaha memenuhi kebutuhan anak baik lahir maupun batin secara proporsional sesuai dengan tingkat perkembangan dan kondisi anak. Mendidik dan memberikan tuntunan merupakan sebaik-baik hadiah dan perhiasan paling indah yang diberikan oleh orang tua kepada anaknya. Sudah menjadi keharusan bagi orang tua dan pendidik untuk bekerja bersama-sama memberikan 
kontribusi secara aktif dan positif dalam membentuk kualitas anak yang cerdas baik secara intelektual, emosional, maupun spritualnya. Perkembangan bahasa atau komunikasi pada anak merupakan salah satu aspek dari tahapan perkembagan anak yang seharusnya tidak luput juga dari perhatian para pendidik pada umumnya dan orang tua pada khususnya. Pemerolehan bahasa oleh anak-anak merupakan prestasi manusia yang paling hebat dan menakjubkan. Oleh sebab itulah masalah ini mendapat perhatian besar. Pemerolehan bahasa telah ditelaah secara intensif sejak lama. Pada saat itu kita telah mempelajari banyak hal mengenai bagaimana anak-anak berbicara, mengerti, dan menggunakan bahasa tetapi sangat sedikit hal yang kita ketahui mengenai proses aktual perkembangan bahasa.

Perkembangan bahasa atau komunikasi pada anak merupakan salah satu aspek dari tahapan perkembagan anak yang seharusnya tidak luput juga dari perhatian para pendidik pada umumnya dan orang tua pada khususnya. Pemerolehan bahasa oleh anak-anak merupakan prestasi manusia yang paling hebat dan menakjubkan. Oleh sebab itulah masalah ini mendapat perhatian besar. Pemerolehan bahasa telah ditelaah secara intensif sejak lama. Pada saat itu kita telah mempelajari banyak hal mengenai bagaimana anak-anak berbicara, mengerti, dan menggunakan bahasa tetapi sangat sedikit hal yang kita ketahui mengenai proses aktual perkembangan bahasa.

Tuntutan harus menguasai beberapa bahasa asing agar dapat berkomunikasi serta saling memahami apa yang dimaksudkan penutur dengan penerima tuturan tersebut. Hal ini disebabkan bahasa adalah salah satu aspek terpenting dalam kehidupan kita serta tidak dapat dipisahkan dalam kegiatan sehari-hari manusia (Anggayana \& Sari, 2018)

Perkembangan fonologi melalui proses yang panjang dari dekode. Sebagian besar konstruksi morfologi anak akan tergantung pada kemampuannya menerima dan memproduksi unit fonologi. Selama usia prasekolah, anak tidak hanya menerima inventaris fonetik dan sistem fonologi tapi juga mengembangkan kemampuan menentukan bunyi mana yang dipakai untuk membedakan makna.

\section{Pemerolehan bahasa}

berkaitan erat dengan bagaimana manusia dapat mempersepsi dan kemudian memahami ujaran orang lain. anak dimanapun juga memperoleh bahasa ibunya dengan memakai strategi yang sama. Kesamaan ini tidak hanya dilandasi oleh biologi dan neurologi manusia yang sama, tetapi juga oleh pandangan mentalistik yang menyatakan bahwa anak telah dibekali dengan bekal kodrati pada saat dilahirkan. Manusia hanya dapat memproduksi ujaran apabila dia memahami aturan-aturan yang harus diikuti yang dia peroleh sejak kecil. Pertanyaan mengapa pemerolehan bahasa pada umur dewasa memunculkan wujud bahasa yang berbeda daripada pemerolehan sejak anak masih kecil berkaitan erat dengan struktur serta organisasi otak manusia.

\section{LANDASAN TEORI}


Brown (1973), pada tahap II verba kanak-kanak tidak berinfleksi. Sekalipun mungkin jelas bagi pendengar dewasa bahwa kanakkanak berbicara mengenai kejadiankejadian yang telah lalu. Suatu kecualian terhadap pola ini adalah bahwa pada awal tahap II kanakkanak dapat mempergunakan kala lalu verba-verba "kuat" atau tidak regular" seperti "went" dan "ran". Kanak-kanak yang memasuki tahap II mengembangkan sejumlah peragkat verba tidak regular dan juga mulai membubuhi infleksi verbaverba regular buat kala lalu, menghasilkan kata-kata seperti "walked; 'believed; dan sebagainya.

Perkembangan fonologi melalui proses yang panjang dari dekode. Sebagian besar konstruksi morfologi anak akan tergantung pada kemampuannya menerima dan memproduksi unit fonologi. Selama usia prasekolah, anak tidak hanya menerima inventaris fonetik dan sistem fonologi tapi juga mengembangkan kemampuan menentukan bunyi mana yang dipakai untuk membedakan makna. Pemerolehan fonologi berkaitan dengan proses konstruksi suku kata yang terdiri dari gabungan vokal dan konsonan. Bahkan dalam babbling, anak menggunakan konsonan-vokal (KV) atau konsonana-vokalkonsonan (KVK). Proses lainnya berkaitan dengan asimilasi dan substitusi sampai pada persepsi dan produksi suara.

\section{Pembelajaran}

bahasa mengacu pada proses pemerolehan bahasa kedua (B2) setelah seorang kanak-kanak memperoleh bahasa pertamanya (B1). Untuk masalah yang dibicarakan ini ada pakar yang menyebut dengan istilah pembelajaran bahasa (language learning) dan ada pula yang menyebut pemerolehan bahasa (language acquisition) kedua. Digunakannya istilah pembelajaran bahasa karena diyakini bahwa bahasa kedua dapat dikuasai hanya dengan proses belajar, dengan cara sengaja dan sadar. Hal ini berbeda dengan penguasaan dengan bahasa pertama atau bahasa ibu yang diperoleh secara ilmiah, secara tidak sadar di dalam lingkungan keluarga pengasuh kanak kanak itu. Bagi mereka yang menggunakan istilah pemerolehan bahasa kedua dan seterusnya beranggapan bahwa bahasa kedua itu juga merupakan sesuatu yang dapat diperoleh, baik secara formal dan informal. Pemerolehan bahasa kedua secara informal ini bias saja terjadi, seperti di daerah pinggiran Jakarta di mana bahasa melayu betawi bertumpang tindih dengan bahasa sunda.

Pengunaan istilah bahasa ibu perlu dilakukan dengan hati-hati. Di kota besar Bahasa ibu seseorang bukanlah bahasa yang dikuasai si ibu sejak lahir. Banyak pasangan suami istri saat berduaan menggunakan bahasa daerah, tetapi bila ada anaknya mereka menggunakan bahasa Indonesia. Dengan demikian bahasa ibu atau bahasa pertama si anak adalah bahasa Indonesia, dan bukan bahasa yang digunakan kedua orang tua mereka. Jadi penggunaan istilah bahasa pertama akan lebih tepat dari pada pengguaan bahasa ibu. Anak anak yang masih dalam masa kritisnya memang mudah untuk belajar bahasa. Contohnya seorang anak balita yang awalnya hidup di Indonesia dengan menggunakan bahasa ibu bahasa Indonesia, kemudian balita itu pindah tempat tinggal di Amerika yang berbahasa 
dengan bahasa inggris. Maka si anak itu dalam waktu singkat akan lupa dengan bahasa yang pertama diperoleh si anak itu, dan hanya bisa berbahasa inggris.

Istilah pembelajaran bahasa digunakan untuk mengacu pada penguasaan bahasa kedua, baik digunakan secara formal di dalam pendidikan formal, maupun secara informal didalam masyarakat sekitar kehudupan si pembelajar. Namun tampaknya pembelajaran bahasa ini lebih mengacu pada pendidikan formal.

1) Dua Tipe Pembelajaran Bahasa Ellis (1986 : 215) Yaitu : tipe naturalistik dan tipe formal di dalam kelas.

Yang pertama tipe naturalistik bersifat alamiah, tanpa pendidik dan tanpa kesengajaan. Pembelajaran berlangsung di dalam lingkungan kehidupan bermasyarakat. Dalam masyarakat bilingual atau multilingual tipe naturalistik banyak dijumpai. Seorang kanak-kanak yang di dalam lingkungan keluarganya menggunakan $\mathrm{B} 1$, misalnya bahasa $X$, begitu keluar dari rumah berjumpa dengan teman-teman lain yang berbahasa lain, misalnya bahasa $\mathrm{Y}$, akan mencoba dan berusaha menggunakan bahasa $\mathrm{Y}$.

Tipe kedua yang bersifat formal berlangsung didalam kelas dengan adanya pendidik dan materi, dan alat-alat bantu yang sudah dipersiapkan. Hasil yang diperoleh secara formal di dalam kelas hasilnya lebih baik dari pada yang naturalistik

2) Sejarah Pembelajaran Bahasa

Kapan dimulai adaya pembelajaran bahasa tidak dapat diketahui dengan pasti. Yang jelas adanya pembelajaran bahasa ini adalah sejak adanya interaksi antara dua masyarakat atau lebih yang memiliki bahasa yang berbeda. Anggota sosial dari masyarakat yang satu tentu akan mempelajari bahasa dari masyarakat yang lain agar dapat berinteraksi dengan anggota masyarakat lain itu. Kemudian karena disadari suatu bahasa lain diperlukan bukan hanya untuk sekadar berinteraksi melainkan juga untuk memenuhi kebutuhankebutuhan lain seperti mempelajari ilmu, maka muncullah lembagalembaga pendidikan yang juga menyajikan pembelajaran bahasa kedua.

\section{3) Hipotesis-Hipotesis} Pembelajaran Bahasa

\section{a. Hipotesis Kesamaan Antara B1 dan B2}

Hipotesis ini menyatakan adanya kesamaan dalam proses belajar B1 dan belajar B2. Kesamaan itu terletak pada urutan pemerolehan struktur bahan, seperti modus interogasi, negasi, dan morfem-morfem gramatikal. Hipotesis ini menyatakan bahwa unsur-unsur bahasa diperoleh dengan urutan-urutan yang diramalkan.

\section{b. Hipotesis Kontrasif}

Hipotesis ini dikembangkan oleh Charles Fries (1945) dan Robert Lado (1957). Hipotesis ini menyatakan bahwa kesalahan yang dibuat dalam belajar B2 adalah karena adanya perbedaan antara B1 dan B2. Sedangkan kemudahan dalam belajar B2 disebabkan oleh adanya kesamaan antara B1 dan B2. Jadi, adanya perbedaan antara B1 dan B2 akan menimbulkan kesulitan dalam belajar B2, yang mungkin juga akan menimbulkan kesalahan, 
sedangkan adanya persamaan antara B1 dan B2 akan menyebabkan terjadinya kemudahan dalam belajar B2.

c. Hipotesis Krashen

Berkenaan dengan proses pemerolehan bahasa, Stephen Krashen mengajukan sembilan buah hipotesis yang saling berkaitan. Kesembilan hipotesis itu adalah: (1) hipotesis perbedaan antara pemerolehan (acquisition) dan belajar (learning), (2) hipotesis urutan alamiah, (3) hipotesis monitor, (4) hipotesis masukan, (5) hipotesis afektif, (6) hipotesis bakat, (7) hipotesis filter, (8) hipotesis bahasa pertama, dan (9) hipotesis variasi individual dalam penggunaan monitor.

\section{METODE PENELITIAN}

Jenis penelitian ini adalah penelitian kualitatif. Dengan metode kualitatif, langkah pertama yang dilakukan yaitu mengadakan penelitian dengan teknik rekamcatat, mentranskrip data, mengelompokkan data sesuai dengan tingkat perkembangan fonologis yang mencakup kefasihan mahasiswa dalam mengucapkan kosa-kata Bahasa inggris pada bidang perhotelan. Menurut Sugiyono (2010:15), penelitian kualitatif adalah metode penelitian yang berlandaskan pada Filsafat postpositivisme, digunakan untuk meneliti pada kondisi obyek yang alamiah, dimana peneliti adalah sebagai instrument kunci, pengambilan sampel sumber data dilakukan secara purposive dan snowball. Teknik pengumpulan dengan triangulasi (gabungan), analisis data bersifat induktif/kualitatif, dan hasil penelitian kualitatif lebih menekankan makna dari pada generalisasi. Penelitian ini menggunakan metode deskriptif, yaitu memaparkan secara verbal mengenai permasalahan yang terdapat pada objek penelitian, teori yang digunakan, analisis data, dan lain sebagainya. Data yang digunakan dalam penelitian ini adalah berupa tindak tutur, yaitu pemerolehan fonologis Bahasa pada peserta didik.

\section{PEMBAHASAN}

Bahasa adalah simbolisasi dari suatu ide atau suatu pemikiran yang ingin dikomunikasikan oleh pengirim pesan dan diterima oleh penerima pesan melalui kode-kode tertentu baik secara verbal maupun nonverbal. Bahasa digunakan anak dalam berkomunikasi dan beradaftasi dengan lingkungannya yang dilakukan untuk bertukar gagasan, pikiran dan emosi. Bahasa dapat juga diekspresikan melalui tulisan, tanda gestural dan musik. Perkembangan bahasa atau komunikasi pada anak merupakan salah satu aspek dari tahap perkembangan anak yang seharusnya tidak luput dari perhatian para pendidik pada umumnya dan orang tua pada khususnya.

\section{Dalam masalah kaitan antara} konsep universal dengan pemerolehan fonologi, ahli yang pandangannya sampai kini belum disanggah orang adalah Roman Jakobson. Dialah yang mengemukakan adanya universal pada bunyi bahasa manusia dan urutan pemerolehan bunyi-bunyi tersebut. Menurut dia, pemerolehan bunyi berjalan selaras dengan kodrat bunyi itu sendiri. Bunyi yang keluar waktu anak mulai berbicara adalah kontras antara konsonan dan vocal. 
Dalam hal vocal, hanya bunyi /a/, /i/, dan /u/ yang akan keluar duluan. Dari ketiga bunyi ini membentuk apa yang dia namakan Sistem Vokal Minimal (Minimal Vocalic System): bahasa manapun di dunia pasti memiliki minimal tiga vocal ini (Jakobson, 1971: 8-20).

\section{a) Teori Struktural Universal}

Teori structural universal ini dikemukakan dn dikembangkan oleh Jakobson (1968). Pada intinya teori ini mencoba menjelaskan pemerolehan fonologi berdasarkan struktur-struktur universal linguistic, yakni hukum-hukum structural yang mengatur setiap perubahan bunyi. Jacobson menyimpulkan adanya dua tahap dalam pemerolehan fonologi, yaitu (1) tahap membabel prabahasa, dan tahap pemerolehan bahasa murni.

Beberapa bukti yang memperkuat teori Jacobson ini adalah sebagai berikut.

a. Bunyi likuida [l] dan [r] yang sering muncul pada tahap membabel, hilang pada tahap mengeluarkan bunyi bahasa yang sebenarnya.

b. Bayi-bayi yang pekak membabel dengan cara yang sama dengan yang normal.

c. Menurut penelitian Port dan Preston (1972), VOT (voice onset time = waktu pelepasan bunyi hambat dan bergetarnya pita suara) seperti konsonan [d] dan [t] tidak sama pada tahap membabel dengan VOT pada tahap mengeluarkan bunyi bahasa yang sebenarnya; dan VOT ketika berusia satu tahun (1:0) sama dengan VOT orang dewasa.

Jika tahap pemerolehan bahasa yang sebenarnya dimulai, maka akan terdapat urutan peringkat perkembangan yang teratur dan tidak berubah, meskipun taraf kemajuan tiap individu berbeda. Perkembangan peringkat ini ditentukan oleh hukumhukum yang bersifat universal yang oleh Jakobson disebut "the laws of irreversible solidarity" (1968 : 68).

Urutan pemerolehan bunyi yang diramalkan Jakobson pada dasarnya sejalan dengan data yang dikumpulkan oleh sejumlah pakar seperti Clark dan Clark (1977), Ervin - Tripp (1966), dan Foss dan Hakes (1978). Data yang dikumpulkan itu menunjukkan bahwa kanak-kanak terlebih dahulu dapat membunyikan [b], [p], [d], dan [t] daripada bunyi [f] dan [s]. Oleh karena itu, sering terjadi [f] ditukar dengan [p], seperti kanakkanak mengucapkan kata [pis] untuk $<$ fish>; atau bunyi [s] ditukar dengan [t] seperti kata <suit> yang diucapkan menjadi kata [tut].

Akhirnya menurut Jakobson, seringnya sesuatu bunyi diucapkan seorang dewasa terhadap kanakkanak tidak menentukan munculnya bunyi tersebut dalam ucapan kanakkanak. Yang menentukan urutan munculnya bunyi-bunyi adalah seringnya bunyi-bunyi itu muncul dalam bahasa-bahasa dunia, maka bunyi-bunyi itu akan lebih dulu muncul dalam ucapan kanak-kanak.

Menurut David Stampe (1972, 1973) proses fonologi kanakkanak bersifat nurani yang harus mengalami penindasan (supresi), pembatasan, dan pengaturan sesuai dengan penuranian (internalization) representasi fonemik orang dewasa.

Suatu proses fonologi terdiri dari kesatuan-kesatuan yang saling bertentangan. Umpanya, terdapat suatu proses ynag menjadikan semua bunyi hambat menjadi tidak 
bersuara dalam semua konteks, karena halangan oralnya menghalangi arus udara yang diperlukan untuk menghasilkan bunyi-bunyi ini. Namun, bagaimanapun bunyi-bunyi ini akan menjadi bersuara oleh proses lain dengan cara asimilasi tertentu. Jika kedua proses ini terjadi bersamaan, maka keduanya akan saling menindih, dan saling bertentangan: sebuah bunyi hambat tidak mungkin secara serentak bersuara dan tidak bersuara pada lingkungan yang sama. Masalah ynag bertentangan ini dapat dipecahkan dengan tiga cara berikut.

a. Menindas salah satu dari kedua proses yang bertentangan itu. Umpanya bila kanak-kanan telah menguasai bunyi-bunyi hambat bersuara dalam semua konteks, maka berarti dia telah berhasil menindasproses penghilangan suara yang ditimbulkan oleh halangan oral bunyi itu.

b. Membatasi jumlah segmen atau jumlah konteks yang terlibat dalam proses itu. Misalnya, proses penghilangan suara dibatasi hanya pada bunyi-bunyi hambat tegang saja, sedangkan bunyi-bunyi hambat longgar tidak dilibatkan.

c. Mengatur erjadinya proses penghilangan bunti suara dna proses pengadaan bunyi suara secara berurutan. Urutannya boleh dimulai dengan proses penghilanga bunyi suara; lalu diikuti dengan proses pengadaan bunyi bersuara. Kedua proses ini tidak mungkin terjadi secara bersamaan.

Berikut diberikan contoh usaha kanak-kanak dalam proses pemerolehan fonologi itu dari ketiga cara diatas. a. Penindasan prosesproses

Seorang anak lelaki berumur dua tahun (2:0) yang diamati Stampe (1972) membunyikan kata "kitty" berturut-turut sebagai berikut dari: [ki] ke [kii] ke [kri] ke [kiri] ke [kiti]. Hal ini dilakukan kanak-kanak dengan dasar proses ketegangan vokal, kemudian penindasan penjatuhan suku kata setengah vokal, setelah itu penindasan proses pengguguran getar, dan akhirnya proses penggetaran.

b. Pembatasan prosesproses

\section{Seorang}

kanak-kanak bernama Hildegard membunyikan semua bunyihambat tak bersuara sebagai bersuara apabila berada di depan segmen bersuara vokal.

[baba] untuk "papa".

Beberapa waktu lalu
kemudian dia membatasi
penyuaraan ini pada hambat yang
berada di antara vokal saja.

a. Pengaturan prosesproses

Kanak-kanak yang bernama Hildegard di atas sewaktu berusia satu tahun delapan bulan (1:8) mengucapkan

\footnotetext{
[du (r)] untuk "juice" [du] untuk "june" d 3 $\longrightarrow d$

[do : i] untuk "joey"

Dari ketiga ucapan di atas dapat ditarik kesimpulan bahwa Hildegard tidak mengucapkan [d ] sehingga menukarnya dengan bunyi
} 
[d]. Namun, jika diteliti lebih jauh benernya dia mampu membunyikan [d3] sehingga terbukti dari ucapannya.

[d3 ui] untuk "church"

[d3 u d u] untuk "choo-

choo"

$$
\mathrm{t} \longrightarrow \mathrm{d}_{3}
$$

Maka Stampe mengambil kesimpulam bahwa Hildegard telah melakukan proses-proses berikut.

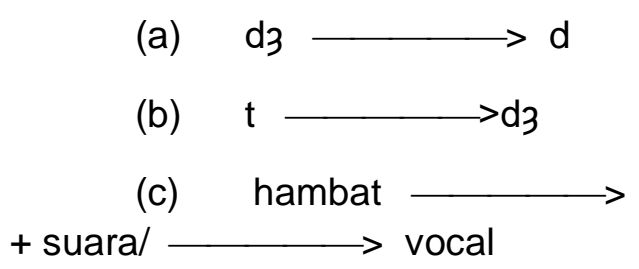

\section{Teori Prosodi- Akuistik}

Teori prosodi- akuistik ini diperkenalkan oleh Weteson (1976) sesudah dia merasa tidak puas dengan pendekatan fonemik segmental yang dikatakannya tidak memberikan gambaran yang sebenarnya mengenai pemerolehan fonologi.

\section{Weterson}

berpendapat bahwa pemerolehan bahasa adalah satu proses sosial sehingga kajianya lebih tepat dilakukan dirumah dalam konteks sosial yang sebenarnya daripada pengkajian data-data eksprimen, lebih-lebih untuk mengetahui pomerolehan fonologi.

Weterson (1970) juga menemukan dan hubungan akuistik antara bentuk-bentuk ucapan kanakkanak dengan fitur-fitur bentuk ucapan orang dewasa. Kanak-kanak hanya mengucapkan kembali bagian ucapan yang makan waktu lebih kurang 0,2 detik, dan bagian yang diucapkan kembali adalah elemen vokal dan konsonan yang mencapai artikulasi kuat.

Tahap-tahap pemerolehan fonologi yang dibuat Ingram di atas sejalan dengan tahap-tahap perkembangan kognitif dari Piaget (1962). Pada tahap persepsi, yang belum produktif itu, terdapat dua subtahap yaitu (a) tahap vokalisasi praucapan, dan (b) tahap fonologi primitif.

Tahap vokalisasi praucapan adalah tahap sebelum kata-kata pertama muncul yang dimulai dengan mendekat ketika berumur empat bulan (0: 4). Kemudian diikuti dengan membabel. Menurut Ingram membabel ini bukanlah kegiatan semaunya, melainkan merupakan suatu kegiatan yang agak teratur, dan maju berkelanjutan. Membabel ini bukan merupakan satu latihan, melainkan ada hubungannya dengan seluruh proses pemerolehan fonologi.

Tahap fonologi primitif muncul pada tahap satu kata (holofrasis) dalam pemerolehan sintaksis. Tahap ini pun belum produktif karenakanak-kanak belum memperoleh rumus-rumus fonologi yang sebenarnya. Sesudah menganalisis data ucapan dari sejumlah kanak-kanak, Ingram menyimpulkan bahwa teori Jakobson tidak seluruhnya benar. Umpamanya, menurut teori Jakobson bentuk suku kata pertama yang muncul adalah $\mathrm{KV}$ atau reduplikasi $\mathrm{KVKV}$; tetapi menurut data bentuk VK juga banyak muncul. Begitu pun bentuk pengulangan yang ditemukan sangat berlainan antara kanak-kanak yang satu dengan kanak-kanak yang lain. 
Pada tahap pengeluaran (yakni tahap proses yang aktif), yang dimulai ketika berusia satu tahun setengah (1:6), terdapat dua peristiwa penting, yaitu:

a.Terjadinya pertumbuhan kosakata dengan cepat. dua kata.

b.Munculnya ucapan-ucapan

Pada tahap ini kanakkanak dimulai mengembangkan kemampuannya untuk menentukan bunyi-bunyi ucapan yang dapat dipakai untuk menyatakan perbedaan makna. Tahap ini berlangsung sampai kanak-kanak berumur tiga tahun enam bulan $(3: 6)$ sampai empat bulan (4:0).

Lebih jauh Ingram juga menemukan bahwa konsonan pertama yang muncul bukan hanya konsonan bilabial seperti pendapat Jakobson, melainkan juga ditemukan konsonan dental dan konsonan frikatif. Namun, konsonan bilabial memang jauh lebih banyak. Begitu juga vokal [u] dan [i] sebagai vokal pertama. Oleh karena itu, menurut Ingram kata-kata yang didengar kanak-kanak sebagai masukan menentukan bunyi-bunyi pertama yang diperoleh kanak-kanak itu. Hal ini bertentangan dengan teori Jakobson yang berpendapat bahwa masukan linguistik (yang didengar oleh kanak-kanak) tidak mempengaruhi pemerolehan fonologinya karena urutan pemerolehan kontras (oposisi) adalah nurani.

Pemerolehan setiap bunyi tidak terjadi secara tiba-tiba dan sendiri-sendiri, melainkan secara perlahan-lahan dan berangsurangsur. Ucapan kanak-kanak selalu berubah antara ucapan yang benar dan tidak benar secara progresif sampai ucapan seperti orang dewasa tercapai. Pemerolehan fonologi kanak-kanak terjadi melalui beberapa proses penyederhanaan umum yang melibatkan semua kelas bunyi. Proses-proses itu adalah:

a. Proses substitusi : penukaran satu segmen oleh segmen lain. Proses ini terjad dari sebagai berikut.

1. Penghentian: bunyi frikatif ditukar dengan bunyi hambat.

$$
\begin{array}{lr}
\text { [sea] [ti :] } \\
\text { [sing] }
\end{array}
$$

2. Pengedepanan: yaitu menukar bunyi velar dan palatal dengan bunyi alveolar

[shoe] [zu']

[shop] [za'p]

3. Peluncuran: yaitu likuida ([i], [r]) ditukar dengan bunyi luncuran (glide) [w]

$$
\text { dan [y] }
$$

[leg]

$$
\text { [yek] }
$$

[ready ] [wedi]

4. Vokalisas: satu suku kata konsonan ditukar dengan satu suku kata vokal

(satu proses yang terutama tegas dalam bahasa Inggris)

[apple] [apo]

[bottle ] [babu] 
5. Netralisasi vokal: bunyibunyi vokal berubah menjadi vokal tengah.

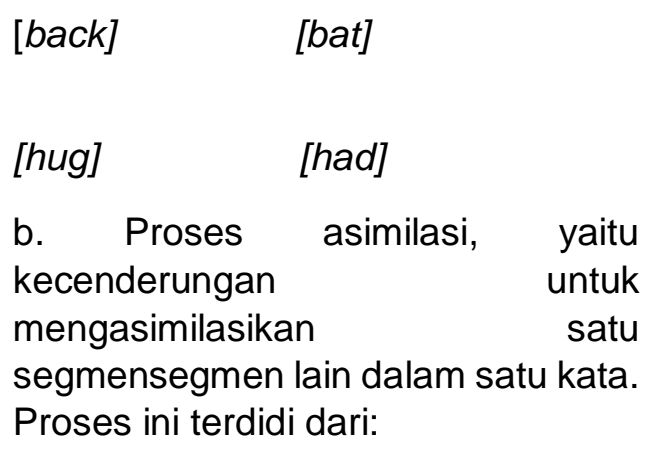
bunyi

1. Penyuaraan, yakni bunyidisuarakan jika

muncul pada akhir suku kata

$\begin{array}{ll}\text { [paper] } & \text { [be :ba] } \\ \text { [tiny } & \text { [daini] } \\ \text { [bird] } & \text { [bit] }\end{array}$

$2 . \quad K e h a r m o n i s a n$ konsonan, yakni bunyi-bunyi konsonan cenderung

berasimilasi satu sama lain. Pola-pola yang sering muncul adalah
(a) Konsonan
apikal cenderung berasimilasi dengan konsonan velar yang berdekatan.
[tongue] [ga]
(b) Konsonan apikal cenderung berasimilasi

dengan konsonan bilabial yang berdekatan.

[tub]

[bab]

[tape] [beip]

3. Asimilasi vokal progresif, yakni sebuah vokal yang tidak mendapat

tekanan diasimilasikan pada vokal yang mendapat tekanan suara yang

muncul di depan atau di belakangnya.

[bacoa] [bu: du]

[hammer] [ha:ma]

c. Proses struktur suku kata, yaitu kecenderungan kanak-kanak menyederhanakan struktur suku kata. Pada umumnya penyederhanaan

suku kata ini berlaku ke arah suku kata KV. Proses ini terdiri dari:

1. Reduksi klaster: satu klaster konsonan direduksikan menjadi satu konsonan saja.

[clown] [kaun]

[play] [pe]

2. Pengguguran konsonan akhir: suku kata KVK dipendekkan menjadi KV dengan menggugurkan konsonan akhir.

[bike] 


\section{[out] [au]}

3. Pengguguran suku kata yang tidak mendapat tekanan digugurkan jika suku kata mendahului satu suku kata yang mendapat tekanan suara.

$\begin{array}{ll}\text { [banana] [naena] } & \\ \text { [potato] } & \text { [pedo] }\end{array}$

4. Reduplikasi: dalam kata panjang suku kata KV diulang.

[cookie]

[gege]

$[T . V]$

[didi]

\section{KESIMPULAN}

Perkembangan fonologi melalui proses yang panjang dari dekode. Sebagian besar konstruksi morfologi anak akan tergantung pada kemampuannya menerima dan memproduksi unit fonologi. Selama usia prasekolah, anak tidak hanya menerima inventaris fonetik dan sistem fonologi tapi juga mengembangkan kemampuan menentukan bunyi mana yang dipakai untuk membedakan makna. Pemerolehan fonologi berkaitan dengan proses konstruksi suku kata yang terdiri dari gabungan vokal dan konsonan. Bahkan dalam babbling, anak menggunakan konsonan-vokal
(KV) atau konsonana-vokalkonsonan (KVK). Proses lainnya berkaitan dengan asimilasi dan substitusi sampai pada persepsi dan produksi suara.

Mengingat bahasa yang dipelajari mahasiswa adalah bahasa Inggris yang mempunyai sistem bunyi yang sangat berbeda dengan bahasa yang telah mereka kuasai, yaitu bahasa Indonesia dan atau bahasa daerah, maka kesulitan pertama yang mereka temukan adalah melafalkan sistem bunyi bahasa yang sedang mereka pelajari yaitu bahasa Inggris. Dari hasil penelitian diketahui bahwa mahasiswa yang mempelajari bahasa Inggris masih melakukan kesalahan dalam melafalkan fonemfonem tertentu. Namun itu merupakan suatu proses yang wajar pada masa perkembangan fonologinya sampai akhirnya nanti mereka mampu berbicara dengan fasih sesuai dengan sistem pengucapan yang benar.

\section{DAFTAR PUSTAKA}

Anggayana, I. W. A., \& Sari, N. L. K. J. P. (2018). Kemampuan Berbicara Bahasa Inggris Mahasiswa Akomodasi Perhotelan: sebuah Kajian Fonologi. Jurnal Manajemen Pelayanan Hotel, 1(1), 8-14. 
Chaer, Abdul. 2002. Psikolinguistik. Jakarta: Rineka Cipta.

Dhieni, Nurbiana. 2005. Metode Pengembangan Bahasa.

Buku Materi Pokok PGTK 2203/Modul

Dardjowidjojo, Soenjono. 2010.

Psikolinguistik (Pengantar

Pemahaman Bahasa

Manusia). Jakarta: Yayasan

Obor Indonesia.

Kartono, Kartini. 2007. Psikologi

Anak. Bandung: Mandar Maju.

Pinker, Steven. Language

Acquisition (last updated on:

11/06/20 (12.20:00:14)p.73.

http://www.arts.uwa.adu.au/

LingWW/

L'N102

99/Notes/theorAcuis. 